\title{
The Value Chain as the Basis of Business Model Design
}

\author{
- Jarmila Strakova, Iveta Simberova, Petra Partlova, Jan Vachal, Robert \\ Zich
}

\begin{abstract}
The article presents a new approach to the generation of business models based on value streams. The originality of the study lies in the assumption that in every business model the generator of added value is the value chain which, if original enough, will maximize potential while minimizing costs. This approach will provide the respective enterprise with a high level competitiveness in the long term. The tested group of enterprises consisted of 354 SMEs, one hundred eightyseven of which were from the manufacturing and industry sector, with 167 from the services sector. The novelty of this approach also consists of the integrated approach to the business environment in which the value streams were analyzed. The results suggest that the analysis of value streams is suitable for the projection of business models. In addition, the methods of dimensional reduction and logit regression have been identified as appropriate analytical tools, with representative results found valid and utilizable in business practice. The authors of the article are aware that this is only the first step in addressing this issue, one which will play a critical role in the gradual process of the upcoming digital transformation of all business models, not only those of SMEs in the Czech Republic.
\end{abstract}

Keywords: business model, value chain, corporate environment, strategy, digitization, competitiveness JEL Classification: L1, 014

Received: September, 2020

1st Revision: February, 2021

Accepted: March, 2021

\section{INTRODUCTION}

There is no agreement among the academic community, and particularly not in the corporate sphere, concerning the definition and understanding of terms such as corporate strategy, business strategy, and business model. The authors of this paper consider the beginnings of the emergence of the business strategy to lie in the period after World War II, when James Culliton (in his paper The Management of Marketing Costs, 1948) and later Neil Borden (The Concept of the Marketing Mix, 1964) came up with the idea of stipulating a product strategy and product portfolio using a marketing mix. Together with Kotler (with his book Marketing Management, 2010), who was primarily responsible for popularizing this issue, these researcher laid the foundations for defining the business strategy of an enterprise. After this beginning, 
various typological strategies came to be used in the literature on strategic management, with Porter's market-oriented approaches becoming the most widely cited. The publications of Michael Porter (Porter, 2012; Porter, 2015) and other authors (Rezapour et al., 2017; Yadav et al., 2017) represented a significant turning point in the approach to the strategies and their generation. Porter defines a strategy as competitive in terms of a corporate strategy.

Meskendahl (2010), Wirtz et al. (2016) describe a business strategy that addresses how the enterprises gain competitive advantage, how they decide to compete in the market, and what business model provides them with a competitive advantage. Yuan et al. (2020) emphasize developing a business strategy with a focus on understanding and adapting to the business and market environment to maximize business performance. Ryu et al. (2015) propose to use one of Porter's three generic competitive strategies. Opinions on this issue continue to differ, although most are based on Porter's work. Porter (2015) has contributed to the way and frequency of projection and implementation of the business models, stating that a good analysis is crucial for the creation of a competitive strategy. Still, it is not reasonable to create one in advance, as it may take several years to find an appropriate approach. He declared that any business issue should be understood as a product of how the enterprise creates value for a customer. The research priority of this topic consists of theoretical finalization and practical verification of a business model that uses the principle of generation of process added value for the customer to achieve a margin. This is based on a description of business processes, their decomposition in the corporate environment, and subsequent value analysis to identify their contributions to the overall margin. A recent aspect is the analysis of the corporate environment's integrity, which respects a system approach to the enterprise, i.e. the authors propose an innovative method for the development of a business strategy or business model based on an analysis of value streams in a company with regard to the integral and unique system of the corporate environment. The structure of this article respects the research goal. A theoretical description of business models and associated mathematical and statistical methods (dimensional reduction and logit regression) is followed by the results of the research. The results section uses optimized logit models to identify not only activities in the value chain that significantly influence the profitability of small and medium enterprises, but also the effects of internal resources as well as the meso and macro environment, including the significance of these components in their integrated form. Finally, the research questions are answered and discussed based on the research outputs. The authors also suggest directions for future research activities in this field.

\section{THEORETICAL BACKGROUND}

Small and medium enterprises represent an important part of a national economic system. The quality of the business environment is critical for these firms, as it can create favorable conditions for their development (Dobes et al., 2017). Kozubikova \& Kotaskova (2019) state that business risks strongly affect the quality of the business environment in which small and medium enterprises operate. These researchers conclude that the primary market risk is the most important risk of all. Lestari et al. (2020) state that for small enterprises, it is essential to set a goal and to share the sources and knowledge that are indispensable for the innovativeness 
of their projects and competitive advantage. Belas et al. (2014) have determined that small and medium enterprises are prone to higher business risks because they are sensitive to changes in the business environment. They explain that SME productivity is affected by obstacles, despite the fact that their contribution to economic growth, employment, and competitiveness is high within the country in which they operate. In the Czech business environment, the terms business and corporate strategy and business model are often confused, and they do in fact overlap.

Apte \& Davis (2019) define a business model as a comprehensive description of the principles of the creation, delivery, and representation of values in an enterprise. The importance of a business model and its connections with a business strategy, innovation management, and economics is also emphasized by Teece (2010). Massa et al. (2017) state that a business model which creates value for the customer and income for the enterprise mirrors the sources of the enterprise that are grouped and arranged in a process producing the value. The relation between the corporate strategy implemented and the business model is discussed by the authors Casadesus-Masanell \& Ricart (2010). Another group of authors indicates that business models can be understood as structured management tools that are considered decisive to corporate profitability and competitiveness (Kharub \& Sharma, 2017; Wirtz et al., 2016). Porter defines the value chain as a powerful tool which makes it possible organize an enterprise into strategically important activities, resulting in the possibility of higher prices and lower costs (Kharub \& Sharma, 2017). The concept of the value chain has also been discussed by a number of other authors, such as Kalmykova et al. (2018), Feller et al. (2006), Missimer et al. (2017), and Kim \& Chai, (2017). Understanding whether a business entity has the potential to create added value and whether it can take advantage of this in the future is an essential step in diagnosing its potential (McNeish \& Kelley, 2019). The research described above have laid the foundation for the study of business model design. Academic works and examples from corporate practice have appeared showing the organization of all categories of corporate strategies and models into a hierarchical and interconnected model. Study results by Marx (2015) provide strong empirical evidence that the Product Strategy (differentiation versus low costs), the Best Value Strategy, and the Blue Ocean Strategy all have a significant influence on corporate management. Wal-Mart is an example of an appropriately configured business model, ensuring as the most important part of the model "everyday low prices" for a wide range of products that are easily accessible and geographically advantageous (Bhavik \& Cespedes, 2016). The current process of generating a business strategy and business models has been deeply influenced by the business and information paradigm which emerged at the beginning of the 21st century. It mirrors changes in the collection, storage, access, and transmission of information (Meskendahl, 2010; Wirtz et al., 2016; Gatautis, 2017), as well as increasingly intensive processes of innovation and digitalization in the corporate environment. Demir et al. (2017) and Dagnino et al. (2017) discuss the increased pace of changes concerning the innovations disrupting the established procedures in industrial branches; the researchers have noticed that the increased speed and intensity of the procedural changes may have a profound impact on strategy and business models. A large number of authors have discussed the progressive digitalization of business strategies (Wirtz et al., 2016; Bharadwaj et al., 2013) and business models (Masanell \& Ricard, 2010; Wirtz et al., 2016). Significant changes have 
also occurred in the global and European market ring, such as the internationalization of trade, the end of globalization and the beginning of "glocalization," and geographical changes from the viewpoint of global economic centers (Wisniewski \& Brzezicka, 2020). Digitization as a current innovation process plays a crucial role in transforming the business models. It provides opportunities for adjusting higher quality and efficiency for the existing business processes and connecting new processes to deliver the maximum added value (Sambit et al., 2017; Martins et al., 2015). Summing up the current degree of scientific knowledge in business modeling, there is no consensus in both the definition and the way of its projection of implementation in business practice. These two attributes were considered at the beginning of the scientific direction of the research by the authors of the paper, its goals, research methods, and the determination of expected theoretical and practical output.

\section{RESEARCH OBJECTIVE, METHODOLOGY AND DATA}

Tresearch aims to prepare a method for business practice for generating a business model of a business using a value chain anchored in its integrated business environment. Two research questions were formulated, which will be decisive for further research in the field of business strategy generation.

RQ1: Is it possible to use value chain analysis, including components of the corporate environment in their integrated form, as a basis for generating a business model?

RQ2: Is sector differentiation of enterprises suitable and sufficient for the development of a business model?

The sample consisted of a total of 354 SMEs. There were 75 micro-enterprises (up to 25 employees, 21\%), 167 small enterprises (25-50 employees, 47\%), and 112 medium-sized enterprises (50 to 250 employees, $32 \%$ ) from the Czech Republic. The manufacturing and industry sector accounted for 187 of the small and medium-sized enterprises (52\%), and the services sector accounted for 167 (48\%) of them. Profitability was reported by $88 \%$ of the sample. The sample was created from the corporate database of the Department of Management at the Institute of Technology and Business. This database was established in 2016 and continues to be expanded. Data collection was conducted primarily through a contact survey $(70 \%)$ and, to a smaller degree, electronic surveying $(30 \%)$. In terms of their representativeness, the source data were consulted with representatives of the business community and the scientific community of the relevant field, including the Czech Statistical Office. The research started in 2016 in a period of economic growth. The first stage was completed in 2019; currently, a follow-up research stage has been underway in conditions of economic stagnation and pandemic crisis. To test value chain activities and components of the corporate environment (internal corporate resources, the meso-environment and the general macro-environment), a dimensionality reduction method is used at first, which reduces information from multidimensional data to a smaller number of variables (Cook \& Lee, 1999; Chiaromonte, et al., 2002), and regression analyses (a general linear model) (Pourghasemi \& Rahmati, 2018; Stoffel et al., 2017). The calculation of dimensionality reduction is based on the inverse distribution $\mathrm{F}(\mathrm{x} \mid \mathrm{y})$. The statistical software 
" $R$ " was used for calculation. A calculation method of dimensionality reduction known as sliced inverse regression (SIR) is used in the analysis. After that, a general linear model (GLM), which makes it possible to express the relation between the dependent variable (in this case, it had a binomial distribution) and a set of explanatory variables (regressors) by means of a regression function, which is a linear function of unknown estimated parameters, was used to determine the optimal model of components of the corporate environment defining the significance of selected internal corporate resources and meso-environmental and macroenvironmental factors. The "Statistica" software was used for calculation.

The link functions used within the logit model (Pourghasemi \& Rahmati, 2018):

$X \beta=\ln (\mu /(1-\mu))$

The integrated model takes account of various dependencies of the tested components of the corporate environment.

$E R \sim I C R+M Z E+M A E+$ company focus;

$\operatorname{glm}($ formula $=E R \sim I C R+M Z E+M A E+$ company focus $)$

Explanatory notes: ER - economic result, ICR - internal resources (microenvironment), MZE - mesoenvironment, MAE - macroenvironment, VC - value chain. (Source: authors)

\section{RESULTS AND DISCUSSION}

The results presented in the paper are based on the assumption that the sample enterprises have a corporate strategy, in many cases identical to the business strategy. The output structure respects the fact that the enterprise operates, delivers products in the customer segment and achieves a margin. The business model is embedded in the enterprise architecture (created mainly by the business environment). In the first part of the research, the value chain within the integrated business environment is analyzed. In the following part, the essential component of the business environment is analyzed using the newly designed integrated model.

\section{Value chain - base of the business models}

$\operatorname{Dr}($ formula $=E R \sim I N L+P R O+O U L+M A R K+R O S+P U R+S T D+H R M+E I$, data $=S S$, PIS, method $=$ "sir")

Value chain variables: INL - input logistics, PRO - production, OUL - output logistics, MARK - marketing and sales, ROS - repair and other services, PUR - purchase/material management, STD - scientific and technical development, HRM - human resource management, EI - enterprise infrastructure, PIS - production and industry sector, SS - service sector, ER - economic result. (Source: authors)

Table 1 shows sector differentiation in terms of the value chain activities tested with regard to their contribution to the creation of value added in the enterprise, in general to the valuecreating business processes. 
Tab. 1 - Dimensional reduction of business value and its impact on profitability in terms of sector differentiation. Source: own research

\begin{tabular}{|l|l|l|}
\hline \multirow{2}{*}{ Value chain activities } & Dir1 & Dir1 \\
\cline { 2 - 3 } & Manufacturing and Industry & Services \\
\hline Input logistics & -0.33510 & -0.01796 \\
\hline Provision of services / production & 0.04738 & -0.21329 \\
\hline Output logistics & 0.58855 & -0.14014 \\
\hline Marketing and sales & 0.42865 & 0.20600 \\
\hline Service and other ancillary services & 0.21481 & 0.22468 \\
\hline Purchase & 0.06062 & 0.34013 \\
\hline Scientific and technological development & 0.18304 & 0.83710 \\
\hline Human Resource Management & -0.44156 & 0.07177 \\
\hline Enterprise infrastructure & -0.27755 & -0.14160 \\
\hline
\end{tabular}

In the manufacturing and industry, output logistics, marketing and sales are the most important activities having a positive impact on the profitability of the enterprises. Human resources management and input logistics have a negative impact, possibly explained by their underestimation by the managers and the poor level of such activities. Increased attention will, for this reason, have to be paid to such activities in the future, with input logistics enhanced by the increasingly intensive process of digitalization and automation, and human resources currently becoming something of a limit to the sustainability and further development of the enterprises since their resources are currently exhausted and will continue to be limited in the future. Different specifics are reflected in the services sector than in the manufacturing and industry sector, with scientific and technical development and purchases labeled as the decisive value-creating activities. It might be the essential requirement for the enterprises in this sector for the accelerated transfer of new research knowledge into business practice. At the same time, purchases are a favored production activity in which the current situation must be stabilized, improved and rationalized with the application of information technology and digitalization.

Tab. 2 - Significance of the value chain by the size of the sample. Source: own research

\begin{tabular}{|l|l|l|l|l|}
\hline & Estimate & Std. Error & Z value & $\mathrm{PR}(>|\mathrm{z}|)$ \\
\hline $\mathrm{VC}-$ micro-enterprises & 0.1623 & 1.5639 & -0.104 & 0.917369 \\
\hline $\mathrm{VC}-$ small enterprises & 4.2620 & 1.4183 & 3.005 & 0.002655 ** \\
\hline $\mathrm{VC}-$ medium-sized enterprises & 1.4587 & 0.8395 & -1.738 & 0.08229. \\
\hline $\mathrm{VC}-$ medium-sized and large enterprises & 2.1818 & 0.5198 & -4.197 & $\begin{array}{l}2.70 \mathrm{e}-05 \\
\text { *** }\end{array}$ \\
\hline
\end{tabular}

As can be seen in Table 1 and the relevant commentary, sectoral differentiation in the sample was not proved. Though, the opposite is true for the categorization by size. The category of mediumsized enterprises shows a statistically lower dependence and according to the subsequent analysis, a number of these enterprises are assembly halls with an ownership structure outside the Czech Republic. Such enterprises do not need to generate business models. 


\section{The internal environment}

$D r$ (formula $=E R \sim M L+E L+O S C+E S T+T E+M T P+P P S+F R C+W L+M R L+B B N+L R D+S E E+$ $T W+I C S+I R S+C C+S E$, data $=S S, P I S$, method $\left.=" s i r^{\prime \prime}\right)$

Internal resource variables: $\mathrm{ML}$ - management level; EL - employees' level; OSC - organization structure of the enterprise; EST - enterprise strategy; TE - technical equipment; MTP manufacturing technology, procedures; PPS - portfolio of products/services; FRC - financial resources of the enterprise; WL - wage level; MRL - marketing level; BBN - brand and business name; LRD - level of research and development; SEE - social environment of the enterprise; TW - training of workers; ICS - information and communication systems; IRS - internal regulations, standards, CC - corporate culture; SE - security; PIS - production and industry sector; SS - service sector; ER - economic result. (Source: authors)

Tab. 3 - Dimensionality reduction of internal corporate resources concerning their influence on value-creating processes - sector differentiation. Source: own research

\begin{tabular}{|l|l|l|}
\hline \multirow{2}{*}{ Internal corporate resources } & Dir1 & Dir1 \\
\cline { 2 - 3 } & Manufacturing and Industry & Services \\
\hline Standard of management & -0.03730 & 0.07425 \\
\hline Standard of employees & -0.06941 & -0.14338 \\
\hline Organizational structure of the enterprise & -0.23548 & 0.32668 \\
\hline Strategy of the enterprise & 0.01945 & -0.03679 \\
\hline Technical equipment & 0.34231 & -0.12071 \\
\hline Manufacturing technology and processes & -0.17705 & 0.29639 \\
\hline Portfolio of products/services & -0.20913 & 0.15683 \\
\hline Financial resources of the enterprise & 0.51449 & 0.54287 \\
\hline Level of wages & 0.10783 & 0.23133 \\
\hline Standard of marketing & -0.06162 & -0.04535 \\
\hline Brand and name & -0.19580 & -0.14826 \\
\hline Standard of research and development & 0.04782 & -0.16157 \\
\hline Social environment of the enterprise & 0.12679 & -0.29993 \\
\hline Education of workers & 0.38789 & -0.08388 \\
\hline Information and communication systems & -0.06305 & -0.21377 \\
\hline Internal regulations and standards & -0.43243 & -0.32077 \\
\hline Corporate culture & 0.21721 & -0.21407 \\
\hline Health and safety & -0.14236 & -0.22153 \\
\hline
\end{tabular}

In the production and industry sector (Table 3), the dominant positive components are the financial resources, staff training, and technical equipment. The internal regulations and standards are adverse. In general, the administrative and legislative burden on the managers is described as unsustainable and restricting the development of the enterprises in the long term. Similarly, the services sector (Table 3) shows the financial resources as the most important part, 
followed by the organizational structure, possibly due to the nature of services. In both sectors, there is a negative effect of the internal regulations and standards related to the administrative burden on the enterprises.

Tab. 4 - Logit regression of internal corporate resources - manufacturing and industry (excerpt). Source: own research

\begin{tabular}{|l|l|l|l|l|}
\hline \multirow{2}{*}{$($ Intercept) } & Estimate & Std. Error & Z value & $\mathrm{PR}(>|\mathrm{z}|)$ \\
\cline { 2 - 5 } & -4.89576 & 1.74341 & -2.808 & $0.00498^{* *}$ \\
\hline Standard of management & -0.05541 & 0.56050 & -0.099 & 0.92124 \\
\hline Standard of employees & 0.88188 & 0.62160 & 1.419 & 0.15598 \\
\hline Organizational structure of the enterprise & 0.54639 & 0.62224 & 0.878 & 0.37989 \\
\hline Strategy of the enterprise & 0.66282 & 0.60651 & 1.093 & 0.27446 \\
\hline Technical equipment & -0.46169 & 0.52686 & -0.876 & 0.38086 \\
\hline Manufacturing technology and processes & -0.07035 & 0.53690 & -0.131 & 0.89575 \\
\hline Portfolio of products/services & 1.16428 & 0.55119 & 2.112 & $0.03466 *$ \\
\hline Financial resources of the enterprise & 0.80622 & 0.50095 & 1.609 & 0.10754 \\
\hline Level of wages & 0.20192 & 0.56787 & 0.356 & 0.72216 \\
\hline Standard of marketing & 0.39847 & 0.48156 & 0.827 & 0.40798 \\
\hline Brand and name & -0.94107 & 0.46705 & -2.015 & $0.04391 *$ \\
\hline
\end{tabular}

Signif. codes: 0 ‘***’ 0.001 '**’ 0.01 '*’ 0.05 ‘’ 0.1 ' ’ 1

Tab. 5 - Logit regression of internal corporate resources -services (excerpt). Source: own research

\begin{tabular}{|l|l|l|l|l|}
\hline \multirow{2}{*}{$($ Intercept) } & Estimate & Std. Error & Z value & $\mathrm{PR}(>|z|)$ \\
\cline { 2 - 5 } & 0.7484 & 1.5007 & 0.499 & 0.6180 \\
\hline Standard of management & 0.5736 & 0.6528 & 0.879 & 0.3795 \\
\hline Standard of employees & -0.4685 & 0.6051 & -0.774 & 0.4388 \\
\hline Organizational structure of the enterprise & 0.8378 & 0.5424 & 1.545 & 0.1224 \\
\hline Strategy of the enterprise & -0.1404 & 0.4767 & -0.295 & 0.7683 \\
\hline Technical equipment & -0.3347 & 0.5314 & -0.630 & 0.5288 \\
\hline Manufacturing technology and processes & 0.8738 & 0.5552 & 1.574 & 0.1155 \\
\hline Portfolio of products/services & 0.3034 & 0.4971 & 0.610 & 0.5416 \\
\hline Financial resources of the enterprise & 1.2937 & 0.5357 & 2.415 & $0.0157 *$ \\
\hline
\end{tabular}

Signif. codes: 0 ‘***’ 0.001 ‘**’ 0.01 '*’ 0.05 ‘’ 0.1 ' ’ 1

Outputs from logit regression in the manufacturing and industry sectors (Table 4) do not correspond to the results of dimensional reduction (Table 3). The most important internal sources in this sector are the brand, name, and portfolio of the enterprise. In the service sector (Table 5), the optimal model of internal sources shows a match with the results of the dimensional reduction (Table 3 ). 
The meso-environment of the enterprise - the framework of corporate competitiveness

$D r($ formula $=E R \sim C O M+S U P+C U S+D I S T R+B P+F I+U N I+R I+L G+P P+G O V+M E D+E A$, dat $a=S S, P I S$, method $="$ sir")

Variables of the environment: COM - competitors, SUP - suppliers, CUS - customers, DISTR - distributors, BP - business partners, FI - financial institutions, UNI - universities, RI - research institutions, LG - local government and self-government, PP - political parties, GOV - government, MED - media, EA - ecology associations, PIS - production and industry sector, SS - service sector, ER - economic result.

Tab. 6 - Dimensionality reduction of the meso-environment from the viewpoint of its influence on corporate value-creating processes - sector differentiation. Source: own research

\begin{tabular}{|l|l|l|}
\hline \multirow{2}{*}{ Meso-environmental factors } & Dir1 & Dir1 \\
\cline { 2 - 3 } & Manufacturing and Industry & Services \\
\hline Competitors & -0.10851 & -0.26964 \\
\hline Suppliers & 0.34066 & 0.09443 \\
\hline Customers & -0.20044 & -0.20991 \\
\hline Distributors & -0.11333 & 0.29382 \\
\hline Business partners & 0.07849 & 0.07443 \\
\hline Financial institutions & -0.13915 & -0.04417 \\
\hline Universities & -0.30523 & -0.68947 \\
\hline $\begin{array}{l}\text { Research institutes, the Czech Academy of } \\
\text { Sciences }\end{array}$ & 0.67923 & 0.21392 \\
\hline Local government & & \\
\hline Political parties & -0.39857 & 0.17977 \\
\hline The government & -0.05315 & -0.30237 \\
\hline The media & 0.20203 & -0.28980 \\
\hline Environmental organizations & 0.13431 & 0.04217 \\
\hline
\end{tabular}

In the production and industry sector (Table 6), the research base (research institutes and the Academy of Sciences of the Czech Republic) is proved to be the most critical component of the environment. However, the enterprises often criticize the lack of cooperation of research institutions and the business practice. The suppliers are also an important part, playing one of the decisive roles in achieving profitability. Higher education and local government and selfgovernment are assessed as harmful components, both of which do not fulfill their mission. They do not contribute to the development of the business sector. The services sector (Table 6) shows no positively evaluated component in terms of corporate profitability. In both sectors, classic competitive forces such as the customers, distributors, business partners, etc., are underestimated and even negatively evaluated by the managers. It might be due to a period of strong economic growth at the time of the research and the overall corporate profitability. The remaining components of the environment, such as the media and environmental associations, are seen as part of the competitive framework but not as crucial to the competitive ring itself. 
Tab. 7 - Logit regression of the meso-environment - manufacturing and industry (excerpt). Source: own research

\begin{tabular}{|l|l|l|l|l|}
\hline \multirow{2}{*}{$($ Intercept) } & Estimate & Std. Error & Z value & $\operatorname{Pr}(>|\mathrm{z}|)$ \\
\cline { 2 - 5 } & 0.81936 & 1.22713 & 0.668 & 0.5043 \\
\hline Competitors & -0.38029 & 0.39915 & -0.953 & 0.3407 \\
\hline Suppliers & 0.50950 & 0.40529 & 1.257 & 0.2087 \\
\hline Customers & -0.47015 & 0.37808 & -1.244 & 0.2137 \\
\hline Distributors & -0.12488 & 0.39675 & -0.315 & 0.7530 \\
\hline Business partners & 0.61540 & 0.43045 & 1.430 & 0.1528 \\
\hline Financial institutions & -0.20019 & 0.36318 & -0.551 & 0.5815 \\
\hline Universities & -1.01401 & 0.64726 & -1.567 & 0.1172 \\
\hline $\begin{array}{l}\text { Research institutes, the Czech Academy of } \\
\text { Sciences }\end{array}$ & 1.35127 & 0.81348 & 1.661 & $0.0967 \bullet$ \\
\hline Local government & -0.73125 & 0.41413 & -1.766 & $0.0774 \bullet$ \\
\hline
\end{tabular}

Signif. codes: 0 ‘***’ 0.001 '**’ 0.01 '*’ 0.05 '? 0.1 ' ’ 1

Tab. 8 - Logit regression of the meso-environment - services (excerpt). Source: own research

\begin{tabular}{|l|l|l|l|l|}
\hline \multirow{2}{*}{$($ Intercept $)$} & Estimate & Std. Error & Z value & $\operatorname{Pr}(>|z|)$ \\
\cline { 2 - 5 } & 4.94644 & 1.51533 & 3.264 & $0.0011^{* *}$ \\
\hline Competitors & -0.71292 & 0.41679 & -1.711 & $0.0872 \bullet$ \\
\hline Suppliers & 0.17497 & 0.40479 & 0.432 & 0.6656 \\
\hline Customers & -0.52647 & 0.44346 & -1.187 & 0.2352 \\
\hline Distributors & 0.81771 & 0.42052 & 1.945 & 0.0518 \\
\hline Business partners & 0.21266 & 0.40057 & 0.531 & 0.5955 \\
\hline Financial institutions & -0.12760 & 0.38326 & -0.333 & 0.7392 \\
\hline Universities & -1.55965 & 0.64070 & -2.434 & $0.0149 *$ \\
\hline
\end{tabular}

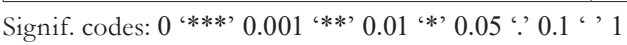

In the manufacturing and industry sectors (Table 7), the results match the dimensional reduction. In the service sector (Table 8), the competitors and distributors are identified as the statistically significant factors, which are the basic competitive forces of the competitive ring.

\section{The macro-environment as a limit to the implementation of business models}

$D r($ formula $=E R \sim D E M+I D+L I F E+E S+C M+L A+G O C+P A T+T E T+O M P P+G D P+I R+I N F+$ $E L C+U N E+G O S+F M R+T P+L E G$, data $=S S, P I S$, method $="$ sir")

Variables of the macro-environment: DEM - demographic development, ID - income distribution, LIFE - lifestyle, ES - education standards, CM - citizen mobility, LA - leisure approach, GOC - governmental costs on research and development, PAT - patents, TET technology transfer, OMPP - obsolesce of the means of production rate, GDP - gross domestic product, GDP - gross domestic product, IR - interest rates, INF - inflation, ELC - enterprise 
life cycle, UNE - unemployment, GOS - government stability, FMR - foreign market regulation, TP - tax policy, LEG - legislation, PIS - Production and Industry Sector, SS - service sector, ER- economic result.

Tab. 9 - Dimensionality reduction of the macro-environment concerning the profitability of corporate entities - sector differentiation. Source: own research

\begin{tabular}{|l|l|l|}
\hline \multirow{2}{*}{ Macro-environmental factors } & Dir1 & Dir1 \\
\cline { 2 - 3 } Demographic development & Manufacturing and Industry & Services \\
\hline Distribution of revenue & 0.30140 & 0.248397 \\
\hline Lifestyle & -0.21124 & -0.387693 \\
\hline Standard of education & -0.05629 & 0.017489 \\
\hline Mobility of the population & -0.30875 & 0.118711 \\
\hline Leisure time & -0.07637 & -0.009306 \\
\hline $\begin{array}{l}\text { Governmental expenditure on research and } \\
\text { development }\end{array}$ & 0.34045 & 0.091724 \\
\hline New patents & -0.40888 & -0.513561 \\
\hline Transfer of technology & 0.17747 & \\
\hline $\begin{array}{l}\text { Degree of obsolescence of means of produc- } \\
\text { tion }\end{array}$ & 0.16900 & 0.22669 \\
\hline Development of GDP & & 0.190347 \\
\hline Interest rates & -0.01290 & 0.208411 \\
\hline Inflation & 0.24363 & -0.237716 \\
\hline Life cycle of company & 0.21879 & 0.335384 \\
\hline Unemployment & -0.03275 & 0.183562 \\
\hline Stability of government & -0.22250 & 0.025467 \\
\hline Regulation of foreign trade & 0.20067 & -0.184754 \\
\hline Tax policy & 0.14805 & 0.282570 \\
\hline Legislation & -0.02846 & -0.069324 \\
\hline
\end{tabular}

The dimensional reduction of the macro environment (Table 9) of the manufacturing and industry sectors shows a positive impact on the profitability of enterprise leisure time activities and demographic developments. Government expenditure on research, development, legislation, and education levels is assessed negatively. In the services sector, interest rates affecting demand for services are positively evaluated, and government spending on $\mathrm{R} \& \mathrm{D}$ and revenue distribution is negatively assessed, suggesting the unavailability of some services for certain population groups. No significant signs of any component of the macro environment in terms of expected impact on their profitability were indicated, mainly due to the pro-growth economic cycle at the time of the research. 


\section{Integrated model of the corporate environment}

$g l m($ formula $=E R \sim I C R+M Z E+M A E$, family = binomial(link = "logit"), data = PIS)

For the SMEs in the manufacturing and industry sectors (Table 10), the statistical dependence of corporate profitability on the business environment is noted. Regarding the significance of environmental components, the highest degree of statistical conclusiveness is in the macro environment; the mean dependence is proved in the meso environment and internal corporate resources.

Tab. 10 - An integrated model of the corporate environment in SMEs - manufacturing and industry. Source: own research

\begin{tabular}{|l|l|l|l|l|}
\hline \multirow{2}{*}{ Intercept) } & Estimate & Std. Error & $\mathrm{Z}$ value & $\operatorname{Pr}(>|z|)$ \\
\cline { 2 - 5 } & -0.01437 & 0.32487 & -0.044 & 0.964719 \\
\hline ICR (internal corporate resources) & 1.42882 & 0.50090 & 2.852 & $0.004338 * *$ \\
\hline MEE (the meso-environment) & 2.03343 & 0.67734 & 3.002 & $0.002682 * *$ \\
\hline MAE (the macro-environment) & 2.24015 & 0.64285 & 3.485 & $0.000493 * * *$ \\
\hline
\end{tabular}

Signif. codes: 0 ‘***’ 0.001 '**’ 0.01 '*’ 0.05 '? 0.1 ' ' 1

$\operatorname{glm}($ formula $=E R \sim I C R+M Z E+M A E$, family = binomial(link = "logit"), data $=S S)$

The results are significantly different for the service sector (Table 11), for which the macro environment does not show statistical significance in terms of its profitability. Here sector differentiation was most pronounced, with over $95 \%$ of the enterprises operating at the local and regional level in the service sector. The rest of the sample consisted of the national and international enterprises unlike manufacturing and industry, for which over $25 \%$ operate at the international level and $45 \%$ at the national level. In the service sector, the current process of globalization is confirmed, and this can also be considered as a novel outcome, as the service enterprises are returning to local, regional customs and traditions as a part of this process.

Tab. 11 - An integrated model of the corporate environment in SMEs - services. Source: own research

\begin{tabular}{|l|l|l|l|l|}
\hline \multirow{2}{*}{ (Intercept) } & Estimate & Std. Error & Z value & $\operatorname{Pr}(>|z|)$ \\
\cline { 2 - 5 } & 4.2756 & 1.1345 & 3.769 & $0.000164 * * *$ \\
\hline ICR (internal corporate resources) & -2.3981 & 0.6291 & -3.812 & $0.000138 * * *$ \\
\hline MEE (the meso-environment) & 2.1102 & 0.6234 & 3.385 & $0.000713 * * *$ \\
\hline MAE (the macro-environment) & -0.6533 & 0.6299 & -1.037 & 0.299663 \\
\hline
\end{tabular}

Signif. codes: 0 ‘***’ 0.001 '**’ 0.01 '*’ 0.05 ‘’ 0.1 ' ’ 1

The authors can objectively conclude that they are not aware of any research activities dealing with similar topics in other EU countries. Some research, however, is available from North America, as mentioned above. Authors analyzed these studies in detail and used them to plan the research activities. Porter (2015) considers the value chain to be the strategic cornerstone of company prosperity. The achieved outputs follow up on research and publications such as Kalmykova et al. 
(2018), Missimer et al. (2017), Kim \& Chai (2017) and others stressing that a value chain offering to customers a unique value should be the core of any business model. De Vries and Van Rensburg (2008) have classified value creation activities as strategic, tactical, operational, and supporting, which confirms the belief that the corporate environment must be approached in terms of integrity in the context of all management levels. McPhee and Wheeler (2006) believe that the value creation process includes the name and reputation of a business entity, its skills and capabilities. Gaidelys \& Dailydka (2014) note that scientists from the United States are seen as the most progressive in the utilization of analytical methods for the evaluation of the corporate environment. Abdulhussien \& Hamza (2012) and Williams \& Naumann (2011) describe that tools such as value chain analysis and benchmarking reduce costs and improve quality of products as well as the rating of the performance of business entities. According to Nouri \& Soltani (2017), the study and practice of enterprise management has been recently facing numerous problems, particularly as a result of dynamic changes in the business environment, changes in technologies (production technologies, information technologies, Internet and e-commerce), growing competition (transition from superto hyper-competition), etc. The first part of the outputs seeks to determine whether value chain analysis is suitable for the development of a business model. The outputs and evaluation of them make it possible to conclude that corporate processes and the related value chain represent a suitable tool for generating a business strategy or a business model. The performed analyses have proved different contributions of the individual components of the value chain to the profitability of enterprises in individual size categories of small and medium enterprises. Another research topic was to identify an appropriate analytical level for corporate value creation processes. The founders of the theory dealing with this topic refer to the industrial branch. Apart from classical authors (Kharub \& Sharma, 2017), also other authors such as Feller et al. (2006), McNeish \& Kelley (2019) believe that the analytical level of the value chain is a specific industrial branch. This is in full conformity with the results, for which in the course of the research the sector level was rejected for the purposes of business model generation. Unlike sector differentiation, for which statistical significance was not demonstrated, the relevance of the value chain for the profitability of enterprises was statistically proved for the size categorization of enterprises. Many studies point to the necessity to also analyze the corporate environment in the context of added value (Virglerová et al., 2017; Nouri \& Soltani, 2017). In general, the authors of the present article have come to similar conclusions as have international authors who have dealt with the same topic, both in terms of the significance of the value chain for both the profitability and sustainability of enterprises, as well as in terms of the industrial branch level as a basis for all future analytical work.

\section{CONCLUSION}

As mentioned in the introductory section, at the outset of their research activities the present authors took into account the growing need and demand of enterprises for new procedures and tools for generating business as well as corporate strategies to achieve competitiveness and sustainability. It is evident that this was one of the critical issues in strategic management and decision making. The focus on creating value in individual corporate processes means a fundamental shift from past procedures and methods used in both in the Czech Republic and abroad. All this has happened in a period of strong economic growth. It should be stated that only enterprises that are innovative as 
well as strategically oriented and managed have been vigilant enough to expect a decline in economic growth and thus a profitability decrease. These enterprises sought new ways towards permanent economic prosperity, even long-term growth. When the authors began the research, they naturally could not foresee that the unprecedented economic boom would be hit by a factor from outside the market environment - governmental measures taken against the covid 19 virus. Despite the clearly adverse effects, it should be objectively observed that the issues addressed in the article have become more important as a result of the current situation. Many companies are already creating practical specific preconditions for the expected changes in the management of their processes, in the approach and projection of their corporate strategies, and focus and implementation of their business policies, all while remaining aware of the fact that the frequently declared "longevity of corporate strategy" of 5 and more years is no longer acceptable. The results presented in this article have been evaluated to answer the two research questions. Based on the outputs, it can be concluded that the value chain is suitable for generating a business model (the first research question). The solution further showed that factoring in the sector level cannot be considered ideal for generating business models, i.e. it is necessary to descend to the level of a specific industrial branch (the second research question). Nevertheless, the factors limiting potential follow-up research which may be classified in two way, as factors related to companies, and factors related to macro-environment with production-technological and economic-financial aspects. According to the long-term monitoring of the corporate sphere, a substantial portion of corporate managers have already been convinced about the necessity to change their approach to a corporate or business strategy, with top managers now dealing with this issue, as authors have seen. The second limitation consists of the uncertainty of development in terms of European and international markets and the expected economic recession, with any confident predictions regarding future development impossible. Despite this climate, the team continues to collect data for this stage of the financial process but, in accordance with the results, only for selected industrial branches that represent a relevant basis for studying the generation of corporate or business strategies.

Acknowledgment: This research is funded by the project titled Digital Transformation for Business Model Innovation of SMSs in the Czech Republic, Reg. No. TL02000215, funded by the Technological Agency Czech Republic (TACR)

\section{References}

1. Abdulhussien, H. M., \& Sadik, H. H. (2012). Strategic Management Accounting Techniques in Romanian Companies: An Empirical Study. Studies in Business and Economics, 7 (2), 126-140.

2. Apte, U. M., \& Davis, M. M. (2019). Sharing Economy Services: Business Model Generation. California Management Review, 61 (2), 104-131. https://doi.org/10.1177/0008125619826025

3. Belás, J., Macháček, J., Bartoš, P., Hlawiczka, R., \& Hudáková, M. (2014). Business risks and the level of entrepreneurial optimism of SME in the Czech and Slovak Republic. Journal of Competitiveness, 6 (2), 30-41. https://doi.org/10.7441/joc.2014.02.03

4. Bharadwaj, A., El Sawy, O. A., Pavlou P. A., \&Venkatraman, N. (2013). Digital Business strategy: toward the next generation of insights. MIS Quarterly, 37 (2), 471-482. https://doi. org/10.25300/MISQ/2013/37:2.3

5. Bhavik, N., P., \& Cespedes, F. V. (2016). Introduction to business stratégy. Journal of the 
American college of radiology, 13 (6), 747-749. https://doi.org/10.1016/j.jacr.2015.11.019

6. Casadesus-Masanell, R., \& Ricart, J. E. (2010). From strategy to business models and onto tactics. Long Range Planning, 43 (2-3), 195-215. https://doi.org/10.1016/j.lrp.2010.01.004

7. Cook, R., \& Lee, H. (1999). Dimension Reduction in Binary Response Regression. Journal of the American Statistical Association, 94 (448), 1187-1200. https://doi.org/10.2307/2669934

8. Dagnino, G. B., King, D. R., \& Tienari, J. (2017). Strategic management of dynamic growth. Long Range Planning, 50 (4), 427-430. https://doi.org/10.1016/j.lrp.2017.06.002

9. Demir, R., Wennberg, K., \& McKelvie, A. (2017). The Strategic Management of High-Growth Firms: A Review and Theoretical Conceptualization. Long Range Planning, 50 (4), 431-456. https://doi.org/10.1016/j.lrp.2016.09.004

10. de Vries, M., \& van Rensburg, A. C. J. (2008). Enterprise Architecture - New business value perspectives. South African Journal of Industrial Engineering, 19 (1), 1-16. Retrieved February 23, 2021, from http://www.scielo.org.za/scielo.php?script=sci_arttext\&pid=S2224$78902008000100002 \& \operatorname{lng}=$ en\&tlng=en

11. Dobeš, K., Kot, S., Kramoliš, J., \& Sopková, G. (2017). The perception of governmental support in the context of competitiveness of SMEs in the Czech Republic. Journal of Competitiveness, 9 (3). http://doi.org/10.7441/joc.2017.03.03

12. Gaidelys, V., \& Dailydka, S. (2014). The potentials of the use of instruments for the assessing of the business environment in the companies of the railway sector, in 8th International Scientific Conference Business and management 2014, 5, 15-16. http://doi.org/10.3846/ bm.2014.059

13. Gatautis, R. (2017). The Rise of the Platforms: Business Model Innovation Perspectives. The Engineering Economics, 28(5), 585-591. http:// doi.org/10.5755/j01.ee.28.5.19579

14. Chiaromonte, F., Cook, R. D., \& Li, B. (2002). Sufficient dimension reduction in regressions with categorical predictors. Annals of Statistics, 30 (2), 475-497. https://doi.org/10.1214/ aos/1021379862

15. Kalmykova, Y., Sadagopan, M., \& Rosado, L. (2018). Circular economy - From review of theories and practices to development of implementation tools. Resources, Conservation and Recycling, 135, 190-201. https://doi.org/10.1016/j.resconrec.2017.10.034

16. Kim, M., \& Chai, S. (2017). The impact of supplier innovativeness, information sharing and strategic sourcing on improving supply chain agility: Global supply chain perspective. International Journal of Production Economics, 187, 42-52. https://doi.org/10.1016/j.ijpe.2017.02.007

17. Kharub, M., \& Sharma, R. (2017). Comparative analyses of competitive advantage using Porter diamond model (the case of MSMEs in Himachal Pradesh). Competitiveness Review, 27 (2), 132-160. https://doi.org/10.1108/CR-02-2016-0007

18. Kozubikova, L. \& Kotaskova, A. (2019). The impact of technological factors on the quality of the business environment. Transformations in Business and Economics, 18 (1), 95-108.

19. Lestari, S. D., Leon, F. M., Widyastuti, S., Brabo, N. A., \& Putra, A. H. P. K. (2020). Antecedents and Consequences of Innovation and Business Strategy on Performance and Competitive Advantage of SMEs. Journal of Asian Finance, Economics and Business, 7 (6), 365-378. https://doi.org/10.13106/jafeb.2020.vol7.no6.365 
20. Martins, L. L., Rindova, V. P., \& Greenbaum, B. E. (2015). Unlocking the Hidden Value of Concepts: A Cognitive Approach to Business Model Innovation. Strategic Entrepreneurship Journal, 9 (1), 99-117. https://doi.org/10.1002/sej.1191

21. Marx, T. G. (2015). The impact of business strategy on leadership. Journal of Strategy and Management, 8 (2), 110-126. http://doi.org/10.1108/JSMA-06-2014-0042

22. Massa, L., Tucci, C. L., \& Afuah, A. (2017). A Critical Assessment of Business Model Research. Academy of Management Annals, 11(1), 73-104. https://doi.org/10.5465/ annals.2014.0072

23. McNeish, D., \& Kelley, K. (2019). Fixed Effects Models Versus Mixed Effects Models for Clustered Data: Reviewing the Approaches, Disentangling the Differences, and Making Recommendations. Psychological Methods, 24 (1), 20-35. https://doi.org/10.1037/met0000182

24. McPhee, W., \& Wheeler, D., 2006. Making the case for the added-value chain. Strategy \& Leadership, 34 (4), 39-46. https://doi.org/10.1108/10878570610676873

25. Meskendahl, S. (2010). The influence of business strategy on project portfolio management and its success - A conceptual framework. International Journal of Project Management, 28 (8), 807-817. http://doi.org/10.1016/j.ijproman.2010.06.007

26. Missimer, M., Robert, K. H. \& Broman, G. (2017). A strategic approach to social sustainability - Part 2: a principle-based definition. Journal of Cleaner Production, 140 (1), 45-52. https://doi. org/10.1016/j.jclepro.2016.04.059

27. Nouri, B.A., \& Soltani, M. (2017). Analyzing the Use of Strategic Management Tools and Techniques between Iranian Firms. Academy of Strategic Management Journal, 16 (1), 1-18.

28. Porter, M. E. (2012). Recent Developments in Competitiveness and Strategy. Porter Prize Conference, Hitotsubashi University. Graduate School of International Corporate Strategy, Tokyo, Japan, December 5, 2012.

29. Porter, M. E. (2015). Shared Value and Strategy. Paper presented at the Shared Value Leadership Summit, FSG, New York, NY, May 12, 2015.

30. Pourghasemi, H. R., \& Rahmati, O. (2018). Prediction of the landslide susceptibility: Which algorithm, which precision? Catena, 162, 177-192. https://doi.org/10.1016/j.catena.2017.11.022

31. Rezapour, S., Farahani, R. Z., \& Pourakbar, M. (2017). Resilient supply chain network design under competition: A case study. European Journal of Operational Research, 259 (3), 1017-1035. https://doi.org/10.1016/j.ejor.2016.11.041

32. Ryu, H., Lee, J., \& Choi, B. (2015). Alignment Between Service Innovation Strategy and Business Strategy and Its Effect on Firm Performance: An Empirical Investigation. IEEE Transactions on Engineering Management, 62 (1), 100-113. http://doi.org/10.1109/ TEM.2014.2362765

33. Sambit, L., Vinit, P., \& Joakin, W. (2017). Digitalization Capabilities as Enablers of Value CoCreation in Servitizing Firms. Psychology \& Marketing, 34 (1), 92-100. http://doi.org/10.1002/ mar.20975

34. Stoffel, M. A., Nakagawa, S., \& Schielzeth, H. (2017). Repeatability estimation and variance decomposition by generalized linear mixed-effects models. Methods in Ecology and Evolution, 8 (11), 1639-1644. https://doi.org/10.1111/2041-210X.12797 
35. Teece, D. J. (2010). Business Models, Business Strategy and Innovation. Long Range Planning, 43 (2-3), 172-194. https://doi.org/10.1016/j.lrp.2009.07.003

36. Virglerová, Z., Homolka, L., Smrčka, L., Lazányi, K., \& Klieštik, T. (2017). Key determinants of the quality of business environment of SMEs in the Czech Republic. E\&M Ekonomie a Management, 20 (2), 87-101. https://doi.org/10.15240/tul/001/2017-2-007

37. Williams, P., \& Naumann, E. (2011). Customer satisfaction and business performance: a firm-level analysis. Journal of Services Marketing, 25 (1), 20-32. https://doi. org $/ 10.1108 / 08876041111107032$

38. Wirtz, W. B., Pistoia, A., Ullrich, S., \& Göttel, V. (2016). Business Models: Origin, Development and Future Research Perspectives. Long Range Planning, 49 (1), 36-54. https:// doi.org/10.1016/j.lrp.2015.04.001

39. Wisniewski, R., \& Brzezicka, J. (2020). Glocal real estate market: evidence from European Countries. Journal of European Real Estate Research, 14 (1), 120-149. https://doi.org/10.1108/ JERER-09-2019-0031

40. Yuan, Y., Lu, L. Y., Tian, G., \& Yu, Y. (2020). Business Strategy and Corporate Social Responsibility. Journal of Business Ethics, 16 (2), 359-377. https://doi.org/10.1007/s10551-0183952-9

41. Yadav, P. L., Han, S. H., \& Kim, H. (2017). Sustaining Competitive Advantage Through Corporate Environmental Performance. Business Strategy and the Environment, 26 (3), 345-357. https://doi.org/10.1002/bse.1921

\section{Contact information}

doc. Ing. Jarmila Strakova Ph.D.

Institute of Technology and Business in Ceské

Budéjovice

Department of Management

Czech Republic

E-mail:strakova@mail.vstecb.cz.

ORCID:0000-0002-3048-3467

doc. PhDr. Iveta Simberova, Ph.D.

Brno University of Technology

Faculty of Business and Management

Czech Republic

E-mail:simberova@fbm.vutbr.c\%.

ORCID:0000-0002-9236-4439

Ing. Petra Partlova, Ph.D.

Institute of Technology and Business in Ceské

Budéjovice

Department of Management

Czech Republic

E-mail:partlova@mail.vstecb.cz.

ORCID: 0000-0003-2404-6073 prof. Ing. Jan Vachal, CSc.

Institute of Technology and Business in Ceské

Budějovice

Department of Management

Crech Republic

E-mail:vachal@mail.vstecb.cz.

ORCID: 0000-0003-0627-1517

doc. Ing. Robert Zich, Ph.D.

Brno University of Technology

Faculty of Business and Management

Czech Republic

E-mail: zich@fbm.vutbr.cz.

ORCID:0000-0001-8335-2834 